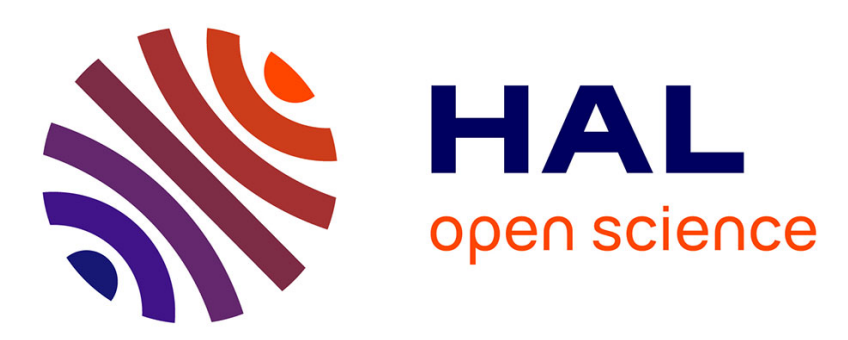

\title{
Tropical microalgae isolated on Reunion island (France, Indian Ocean) as sources of antifouling molecules: The BIOPAINTROP project
}

\author{
Laurent Dufossé, Alexis Bazire, Yves Blache, Laurent Blériot, Christine
} Bressy, Jean-François Briand, Dalyal Copin, Gérald Culioli, Maxime Delbury, Fabienne Faÿ, et al.

\section{To cite this version:}

Laurent Dufossé, Alexis Bazire, Yves Blache, Laurent Blériot, Christine Bressy, et al.. Tropical microalgae isolated on Reunion island (France, Indian Ocean) as sources of antifouling molecules: The BIOPAINTROP project. New Biotechnology, 2016, 33, 10.1016/j.nbt.2016.06.749 . hal-01734752

HAL Id: hal-01734752

https://hal.science/hal-01734752

Submitted on 15 Mar 2018

HAL is a multi-disciplinary open access archive for the deposit and dissemination of scientific research documents, whether they are published or not. The documents may come from teaching and research institutions in France or abroad, or from public or private research centers.
L'archive ouverte pluridisciplinaire HAL, est destinée au dépôt et à la diffusion de documents scientifiques de niveau recherche, publiés ou non, émanant des établissements d'enseignement et de recherche français ou étrangers, des laboratoires publics ou privés. 


\section{Tropical microalgae isolated on Reunion island (France, Indian Ocean) as sources of antifouling molecules: The BIOPAINTROP project}

Laurent Dufossé5,*, Alexis Bazire 1, Yves Blache2, Laurent

Bleriot 3, Christine Bressy2, Jean-Franc, ois Briand2, Dalyal Copin1, Gerald Culioli 2, Maxime Delbury4, Fabienne Fay6, Isabelle Grondin7, Isabelle Linossier 1, Ludovic Mangrie3, Karine Rehel8, Pierre Sauleau8, Thierry Taye3, Alina Tunin-Ley9, Jean Turquet9, Claudia Zea Obando8, Mayalen Zubia10

1 Universite de Bretagne Sud, France

2 Universite de Toulon, France

3 Bioalgostral, France

4 NAUTIX, France

5 University of Reunion Island, France

6 Univ UBS, France

7 Universite de La Reunion, France

8 UBS, France

9 Hydro, France

10 Universite de Polynesie Franc, aise, France

Biofouling is associated to colonization of artificial submerged structures by aquatic organisms. This process induces adverse effects such as loss of hydrodynamism, corrosion, weight increase of equipments. Numerous toxic compounds (copper, arsenic) have been used during decades to avoid biofouling of ships, until EU has banned them since 2008. For this reason, a new strategy, focusing on environmental friendly molecules is requested aiming to provide coatings that progressively release active natural compounds, non-toxic for environment. As a significant component of marine organisms, microalgae are a promising source of active natural substances, with biotechnological potential value. Growing microalgae is a worldwide project for various purposes actually 
e.g. biofuel. BIOPAINTROP project aims to develop antifouling coatings with active biomolecules originating from tropical marine resources (microalgae) from Reunion Island. Two main objectives have been designated: (i) identification of active molecules from tropical microalgae and (ii) incorporation of these compounds in adequate coatings and confirmation of the efficiency of these products in both temperate and tropical marine environments. To reach the targeted results, a pluridisciplinary group has been set up with 6 French teams with complementary expertises: (i) HYDRO based on Reunion island and specialized in tropical marine microalgae, (ii) three University laboratories: LCSNSA (Reunion) specialized in natural products valorisation; LBCM (Bretagne) specialized in marine biotechnologies; MAPIEM (Toulon) specialized in polymer materials engineering and marine biocompounds, (iii) Private partners: NAUTIX producing environmental friendly paints, expert in processing ecological and antifouling coatings; BIOALGOSTRAL a start-up from Reunion specialized in production/valorisation of microalgae biomass. 